\title{
The Difficulties in the Teaching of Traditional Business Schools and the Rise of Teaching Models in New Business Schools
}

\author{
Liang Huang ${ }^{a}$, Haowei $\mathrm{Ti}^{\mathrm{b}}$ \\ Hong Kong Asia Business Collage, Dongguan 523000, China \\ a188288725@qq.com, bhuntertee@foxmail.com
}

\begin{abstract}
It is generally believed that business schools are places where social business elites are created. Just like doctors trained in medical schools, everything is natural, but in fact it is not. After a series of selection and national unified examinations, you successfully entered the business school to study, and after the guidance and thesis defense of the professors, you will be able to graduate smoothly. But when you got to the workplace, you found that it was totally different from what you taught in the business school. The outline of the papers and the actual situation in the actual application are out of place. In practice-oriented disciplines, elegant closed-door vehicles and linguistic figures are made, but few of them are based on actual business practice models, and have nothing to do with specific practices. The guiding significance of practice is almost non-existent. Usually, business school professors guide papers, starting with data, using regression analysis, data analysis, and various data tools to test hypothesis theory, without entering a specific commercial society. Instead, imagine a simulation experiment, a hypothetical R\&D project, and in the case of a lab, guess what the next step will be. These methods are partly useful and inspiring, but they are kept at a great distance from the actual operation. Research often does not reflect the actual way of doing business. Management should be an activity that explores the activities of social groups, focusing on practical and vocational development. Business activity management is carried out in activities, making reasonable judgments in incomplete and incoherent data. The new business school advocates learning and summarizing in business practice, breaking the boundaries of knowledge and summarizing the theory of management in real business activities. The cases in teaching are the actual cases encountered in the actual work, and are summarized through specific practices. According to the changes in the market economy under the influence of the big environment, the teaching content will also change to meet the needs of the market. The new business school does not take the test results as the main measurement standard, and aims at the company's profit, and cultivates more talents suitable for enterprise development as the main teaching tenet.
\end{abstract}

Keywords: traditional business school; dilemma; new business school.

\section{Introduction}

In the traditional business school, you can learn a lot of management knowledge, not necessarily learning management ability, that is, learning is difficult to get practice. The reason is: professors and teachers are not close to practice, looking for cases in the book all day long, behind closed doors to build a car. Management theory and management practice knowledge, the gap seems to be very far away.

Textbooks and theoretical knowledge, it is impossible to list all the conditions of use, even if several common conditions are listed, his important order is not arranged; Even if you grasp the most critical conditions of use, the degree of maturity of the conditions can only be grasped in practical experience. It is impossible to tell you in the book: Under the new conditions, whether the conditions are mature;

Management is more like a craft. The traditional business school teaching mode can't convey the hand feeling, texture rhythm, timing, heat and various degrees of skill.

If the teaching has no situational style, the study of practical content, only the theoretical concept of the mountain and the static analysis framework, cannot learn the essence of management. 
Although the case teaching and MBA consulting projects have been added to the teaching, the mainstream is still teaching explicit knowledge, without the pioneering spirit of business learning, entrepreneurship and entrepreneurship. Because professors rarely do real business management, if they can do well, he has long been a professional manager.

Peter Drucker said that management is a discipline. This first means that management is put into practice rather than economics, not measurement, not behavioral science. Whether it is economics, measurement or behavioral science, it is just a tool for managers. However, it is not economics that managers put into practice. It is not like a blood test that a doctor puts into practice. It is not the behavioral science that managers put into practice. It is not like a microscope that a biologist puts into practice. It is not the measurement method that managers put into practice. It is not the case that a lawyer puts it into practice. Management is put into practice by management.

It's hard to imagine that a professor at a medical school has no clinical experience, has not seen a patient, and can teach a student to be a qualified doctor. A law professor, who has never been a lawsuit, has gone to court, teaches students how to be lawyers and judges; a professor who has no management experience and business practice can teach management with peace of mind. The same is true.

\section{The Dilemma Faced by Traditional Business Schools}

The traditional business school has a relatively simple teaching model. The traditional classroom teaching is guided by the test results, and the passing of the exam is fine. After you have successfully finished your thesis and published it as required, you will be able to graduate successfully.

Traditional business teaching, students basically do not learn the five mentality of training managers, that is, the self-reflective mentality of management, the cooperative mentality of management relationship, the analytical mentality of management organization, the mentality of management environment, and the operational mentality of management change. The professor will not use this to design the course;

The content of the teaching is basically not updated. It is based on the specific content of the textbook and the edited PPT. Changes in the economic environment, the quality of teaching content, does not seem to affect the professor's salary.

In the teaching requirements of traditional business schools, there is no company's profit requirement, and there is no need to do profit analysis and cost accounting for specific work. Changes in market demand are not related to the teaching of traditional business schools. The enrollment conditions of business schools will not lower the enrollment standards and scores according to changes in the market economy.

In the future work, many of the classroom contents taught by traditional business schools are outdated knowledge. This will undoubtedly have a big gap for students.

\section{How to Solve the Dilemma of Traditional Business Schools and the Rise of New Business Schools}

Traditional business teaching, study classes at school from Monday to Friday, regular time classes, and colleges and universities will implement the elective system, and choose which time of the week to attend classes. You can apply for a dormitory. During the study period, the files and accounts will be transferred to the school, and formal employment will not be allowed during the school period; that means there is no income.

The teaching location is fixed and can only be taught on the university campus. There is no flexibility to talk about. Traditional MBA programs require students to attend classes, complete part of the course, and complete group assignments, including reading, lectures, text-based assignments, and audio and multimedia formats. Students need to complete all course content in the classroom.

After decades of continuous development of MBA education, the traditional education model based on theoretical teaching can no longer meet the needs of contemporary students. Only the reform education model can make MBA education shine in the fierce international competition. The current 
MBA students have three major characteristics: First, the students are getting younger and less experienced in management; second, the students are pursuing speculative learning, that is, taking questions to find answers; third, the students are cultivating demand for innovative thinking. They think greater than the need for a diploma.

The new business school does not take the exam as the main basis for the selection of materials, and carries out the part-time postgraduate teaching model according to market demand. New Business School is committed to developing students' keen business thinking skills and leadership in social responsibility, providing a platform for transforming and upgrading future business leaders.

New business school is committed to cultivating more new professional managers; Professional managers as entrepreneurs must have entrepreneurial thinking, including finding and judging opportunities, and enabling them to have long-term sustainable development capabilities. There are many MBA students who have entrepreneurial experience, or entrepreneurial planning, new business teaching compulsory course entrepreneurship management and related elective courses, so that students can further systematically learn and strengthen entrepreneurial thinking and management skills, and understand how to pass growth creates value.

The new business school especially emphasizes the self-examination and mutual support of the book concept and its own management experience, and thus creates many ways to extend management education beyond the classroom, such as reflective work, exchange visits, on-site research, entrepreneurial activities, etc.

In a complex and volatile global economic environment, professional managers must have a global and local vision, the ability to handle complex problems and respond to rapid changes, and be good at leading innovation. They must be able to effectively communicate with different stakeholders and form a shared vision and goals for the company's operations.

\section{Characteristics and Advantages of New Business School}

Guided by business practice, with the goal of cultivating talents for enterprises, it is to achieve "decentralization", no longer use the fixed classroom of the university as the main teaching center, and not to focus on teaching as a single teaching mode. Where the students are more concentrated, where to prepare for classroom teaching. At the same time, it is also possible to implement a mobile classroom, arrange it in the enterprise, and use field trips as teaching content to conduct real-life teaching. Using more scientific means to achieve distance learning, students do not have to go to class to attend classes. Courseware content can also be sent directly to students.

Flexible and diverse teaching methods. The teaching methods of each course are different. With the rich experience of professors in the academic and business circles, lectures and case studies have become very vivid. The new business teaching is selected from the case of top business schools such as Harvard Business School, Stanford Business School, Lausanne International School of Management, INSEAD, IESE, etc. The textbooks are also derived from various recent resources such as academic journals, magazines and videotapes. Some courses also take different teaching methods, such as practical simulations, guest lectures and seminars. The teaching of new business studies focuses on the student experience and does not follow the traditional formalistic teaching of traditional business.

Enrollment goals are no longer simple students, more business managers, business owners, etc., no longer subject to traditional business school scores, indicators and other requirements. Instead of using papers as the ultimate goal, no more exam requirements will be set, and no professors will limit the papers. In this way, more people who are knowledgeable will study business courses, and the goal of enrollment will be wide-ranging and will be further expanded.

The learning cost of new business and the efficiency of receiving results become higher, and the time of input and output is greatly shortened. Students and in-depth exchanges with entrepreneurs from different industries, comprehensive understanding of market development and corporate vitality from a variety of perspectives, and with senior industry insiders to explore the road to future transformation and upgrading. 
In the teaching process, classmates exchange is more likely to generate business opportunities, and promote more company cooperation and strong alliance. In addition to its own value added, it can achieve more business value.

New business is no longer centered on universities and professors, and more students are the center. At the same time, the professors who participate in the teaching use the employment system, the professors who are suitable for the new business environment will be hired, and the more paid will be several times more than the salary of the traditional business professor. The quality of teaching is based on student ratings and will not be affected by the system. The flexibility of the course will also be adjusted and updated as the economic market changes.

\section{Conclusion}

The modern economic environment is constantly changing. The business teaching model and methods need to adapt to economic and social development and constantly carry out changes and adjustments. Introducing more overseas new teaching methods, and referring to more new overseas cases and teaching materials to further develop the international perspective of students, in order to cultivate more business elites and business leaders.

\section{References}

[1]. Gu Jisheng, Guo Linyan. (2005)"Domestic Business Teaching: Status, Trends and Reform." Journal of Shanxi Normal University: Social Science Edition 32. 5: 40-44.

[2]. Tian Zhilong, and Zhong Wenfeng. (2018) "The development of local Chinese management: theoretical development, practical challenges and issues to be studied - "China Management 50 People" Forum (2018 first half) Side Notes of the meeting. "Journal of Management 15.7: 957.

[3]. Wang Wei. (2015) "The new ten-year re-launch "Changjiang Business School EMBA Five New Decade Future Forum" is the perfect ending." Youpin 12: 100-103. 